\title{
Molecular Identification of Leptospira interrogans in Naturally Infected Cows from a Rural Property in the Border Region
}

\section{Identificação molecular de Leptospira interrogans em Vacas naturalmente infectadas de uma propriedade rural em Região Fronteiriça}

\author{
Giovani Batista Pastre ${ }^{1}$; Isabela Carvalho dos Santos ${ }^{1}$; Robson Michael Delai ${ }^{1}$; \\ Edinalva Madalena de Almeida Mota ${ }^{1}$; Lidiane Nunes Barbosa ${ }^{2}$; Roberta Torres \\ Chideroli³; Lucienne Garcia Pretto-Giordano ${ }^{4}$; Luiz Rômulo Alberton²; Ulisses de \\ Pádua Pereira ${ }^{4}$; Daniela Dib Gonçalves ${ }^{2 *}$
}

\section{Highlights:}

Infectious disease present on border region dairy property.

Molecular diagnosis revealed by sequencing that showed the presence of Leptospira interrogans.

L. interrogans can survive up to 200 days under ideal conditions of water and wet soil.

\begin{abstract}
The aim of this study was to investigate the antibodies and DNA of Leptospira spp. isolated from infected cattle in a small rural dairy farm in a border region between Brazil and Paraguay. Blood and urine samples were collected from 50 Holstein cows aged between 1 and 15 years. The diagnostic tests performed were microscopic serum agglutination for antibody detection and polymerase chain reaction for Leptospira spp. detection. Out of the samples analyzed, $48 \%$ were MAT positive with titers ranging from 100 to 400, and the most prevalent antibody was to the serovar Hardjo. One serum sample was amplified to $549 \mathrm{bp}$ for the $\sec$ y gene, and sequencing identified it as L. interrogans. This is the first report from northwestern Paraná (PR) State of L. interrogans identification in naturally infected milk cattle. Thus, based on these results, to enhance production efficiency, new serological and molecular studies on dairy cattle from border regions are required to characterize the epidemiology of possible genotypes and their consequences in affected herds.
\end{abstract}

Key words: Spirochetes. Diagnosis. Leptospirosis. Ruminants. One Health.

\footnotetext{
1 Discentes de Doutorado, Programa de Pós-Graduação em Ciência Animal com Ênfase em Produtos Bioativos, Universidade Paranaense, UNIPAR, Umuarama, PR, Brasil. E-mail: giovani.pastre@virbac.com.br; isabela_carvalhoxd@hotmail.com; rmdelai@gmail.com; edinalvamotarosa@gmail.com

2 Profs., Programa de Pós-Graduação em Ciência Animal com Ênfase em Produtos Bioativos, Universidade Paranaense, UNIPAR, Umuarama, PR, Brasil. E-mail: lidianebarbosa@prof.unipar.br, romulo@unipar.br; danieladib@prof.unipar.br

3 Discente de Doutorado, Programa Pós-Graduação em Ciência Animal, Universidade Estadual de Londrina, UEL, Londrina, PR, Brasil. E-mail: ro.vetuel@gmail.com

4 Pesquisadores, Departamento de Medicina Veterinária Preventiva, UEL, Londrina, PR, Brasil. E-mail: luciennegiordano@gmail. com; upaduapereira@gmail.com

* Author for correspondence
} 


\section{Resumo}

O objetivo deste trabalho foi pesquisar anticorpos e DNA de Leptospira spp. em uma propriedade rural leiteira de uma região fronteiriça entre Brasil e Paraguai. Foram coletadas amostras de sangue e urina de 50 animais da raça Holandesa com idade variando de um a quinze anos, de uma pequena propriedade rural de exploração leiteira em uma região de fronteira entre Brasil e Paraguai. Quanto aos diferentes diagnósticos foi utilizado a soroaglutinação microscópica para a detecção de anticorpos e também foi realizada a reação em cadeia pela polimerase para a detecção de DNA de Leptospira spp. Das amostras analisadas, $48,00 \%$ foram soro reagentes na SAM com títulos variando de 100 a 400 e o anticorpo contra o sorovar mais prevalente foi o Hardjo. Uma amostra de soro amplificou 549pb para o gene sec y, e no sequenciamento foi identificada como Leptospira interrogans. Este é o primeiro relato da região noroeste do estado do Paraná (PR) relacionado à identificação de L. interrogans de bovinos de leite naturalmente infectados e em virtude dos resultados deste trabalho são necessários novos estudos sorológicos e moleculares em criações de gado de leite de regiões fronteiriças para se caracterizar a epidemiologia dos possíveis genótipos e suas possíveis consequências nos rebanhos afetados visando sempre à eficiência da produção.

Palavras-chave: Espiroquetas. Diagnóstico. Leptospirose. Ruminantes. Saúde Única.

\section{Introduction}

Brazil (1979) clarifies that a border fringe region is defined at $150 \mathrm{~km}$ wide, parallel to the dividing line of the land boundary of the national territory. Brazil has $15,735 \mathrm{~km}$ of border with ten neighboring countries being, in the north with French Guiana, Suriname, Guyana and Venezuela, in the northwest with Colombia, in the west with Peru and Bolivia, in the southwest with Paraguay and Argentina and in the south with Uruguay (Souto et al., 2016).

The current state of national livestock farming with a strong need for globalization can lead to the entry of pathogens mainly in regions close to international borders. These regions present a high risk for the presence of pathogens from cattle and identifying these is of great importance as a precaution for possible future problems in herds (Vasconcellos et al., 1997).

Some studies show the vulnerability of our borders, since the integration between countries and populations of the world is increasing, and the tendency is to reduce barriers at national borders to expand the market, increasing the risk of entry and dissemination of microorganisms (Freitas, 2008).

Leptospira spp. is considered a bacterium of great interest in public health because it causes a zoonosis that is endemic globally and affects cattle (McBride, Athanazio, Reis, \& Ko, 2005). In bovine species, transmission occurs mainly by direct exposure to the urine of infected animals, and the agent can be eliminated for several months, even after clinical cure (Faine, Adler, Bolin, \& Perolat, 1999). Therefore, the aim of this study was to investigate the antibodies and DNA of Leptospira spp. isolated from infected cows in a small rural dairy farm in a border region between Brazil and Paraguay.

\section{Case Report}

During the first six months of 2018, blood and urine samples were collected from 50 Holstein cows were asymptomatic for any disease ranging from one to 15 years old from a small farm in the municipality of Umuarama, northwestern Paraná (PR) State, located $135 \mathrm{~km}$ from Paraguay; therefore, is considered a border region (Lei ${ }^{\circ}$ $6.634,1979)$. The property had simple facilities, just a corral and the location of the milking place. The property's production system was semiextensive, that is, the animals are raised on pasture and fed with high support capacity forages, with supplemental supplementation at the time of lower 
pasture growth. At the time of blood collection, the animals were presenting a decrease in milk production, abortions, and difficulty breeding, and it was confirmed by the farmer that the animals were not vaccinated for leptospirosis.

The blood collections were realized by puncturing the jugular vein where approximately 10 $\mathrm{mL}$ of blood was collected and stored in sterile tubes without anticoagulant. Later, urine was collected in Falcon tubes $(15 \mathrm{~mL})$ by vaginal massage and both were sent to the laboratory for the diagnosis.

To detect anti-Leptospira spp., sera were submitted to the Microscopic Agglutination Test (MAT) with live antigens (Faine et al., 1999). A total of 20 serovars were used: Australis, Bratislava, Autumnalis, Butembo, Castellonis, Bataviae, Canicola, Cynopteri, Grippotyphosa, Hebdomadis, Copenhageni, Icterohaemorrhagiae, Panama, Pomona, Pyrogenes, Hardjo, Wolffi, Shermani, Sentot, and Tarassovi. A 1:100 dilution was used as the cut-off point (Faine et al., 1999).

Serum containing at least $50 \%$ of the agglutinated leptospires were reagents and the reagent samples were geometrically diluted 2-fold to determine the maximum positive dilution. The analysis of the results considered the serovar as that which had the highest titer and (Vasconcellos et al., 1997) the sera that showed coagglutination at the highest dilution were considered reagents for Leptospira spp. (Almeida, Martins, Brod, \& Germano, 1994).

To detect Leptospira spp. DNA, urine and blood were submitted to molecular tests. DNA from the serum and urine samples was extracted immediately after each collection using the PureLink Genomic DNA Mini Kit. The DNA, then submitted to PCR using specific primers for the partial sec $\mathrm{Y}$ gene (F 5'-ATGCCGATCATTTTTGCTTC-3' and R 5'-CCGTCCCTTAATTTTAGACTTCTTC-3') to identify and confirm the genetic species (Ahmed et al., 2006). Negative control (ultra-pure water) and positive control (strain Hardjo) were also used in the reaction. The final PCR amplification product was subjected to $1.5 \%$ agarose gel electrophoresis stained with GelRed and the visualization was performed using a transilluminator with ultraviolet light. The molecular weight was estimated by comparison relative to the $100 \mathrm{bp}$ molecular marker and visualization was performed in an ultraviolet trans illuminator where the positive sample aligned with 549bp.

The products of sec $\mathrm{Y}$ were purified with a Purelink Genomic DNA extraction kit and sequenced in the ABI3500 Genetic Analyzer using the forward and reverse primers that were employed in the PCR. The sequences obtained were analyzed in the MEGA 6.06 program and compared to the GenBank databases using the Blastn tool (https:// blast.ncbi.nlm.nih.gov/Blast.cgi) from the National Center for Biotechnology Database Information. A percent identity of $100 \%$ of the reference sequence was considered when compared to the submitted sequence.

Serological diagnosis showed 24 (48.00\%) sera samples reagents to the MAT with antibody titers varying from 100 to 400 . Antibodies against a single serovar were detected in 14 (58.34\%) samples. From the Sejroe serogroup five (3.57\%) reacted to Hardjo and three (2.14\%) to Wolfii, from the Tarassovi serogroup three $(2.14 \%)$ reacted to Tarassovi, from the Ballum serogroup two (1.42\%) reacted to Castellonis and Pomona serogroup one $(0.71 \%)$ reacted to Pomona. In ten $(41.66 \%)$ samples, antibodies against two or more serovars were detected simultaneously, and it was not possible to characterize the most probable serovar.

Molecular diagnosis of the sera samples revealed one $(2.0 \%)$ sample amplified for the sec $\mathrm{Y}$ gene followed by sequencing that showed the presence of L. interrogans (GenBank: BankIt2195108 Seq1 MK537340). This sequenced sample was also reagent in MAT showing a titer of 400 for the antibody to the serovar Hardjo. Molecular diagnosis of the urine samples did not detect any Leptospira spp. DNA. 
In the present study, $48 \%$ of the animals were serareagents. In northwestern Paraná (PR) State, similar results were found by Hashimoto et al. (2015) who detected $41.13 \%$ serareagents animals from different herds and A. F. Oliveira et al. (2018) who detected $42.30 \%$ seroreagents females (discarded animals) from two slaughterhouses. These results suggest possible previous exposure of these animals to Leptospira spp., demonstrating the epidemiological situation in this region.

Leptospirosis prevalence in bovine herds varies greatly from region to region since it is dependent on some factors, such as the presence of animal carriers and bacterium elimination through urine causing environmental contamination with live leptospires, which in turn makes other animals and humans susceptible to the infection (Faine et al., 1999).

The high rate of animal replacement could facilitate the introduction of different etiological agents, such as Leptospira spp., when performed without verification of the animals' health status via vaccination records. Also, northwestern Paraná borders the states of São Paulo (SP) and Mato Grosso do Sul (MS), in addition to being bordered by Paraguay, and consequently there is a high transit of animals between the states and with the neighboring country, which may further increase the risk of infection by Leptospira spp.

In Brazil, most borders are considered free, allowing animals to be moved easily. This occurs animals when are bought from neighboring countries owing to more affordable prices, and with the exchange of animals of different categories, such as the exchange of heifers, male calves for fattening, or vice versa (Ungerer \& Reais, 2017). This situation is similar to that of the present study owing to the proximity of the study site to Paraguay.

The antibody to the serovar Hardjo was the most prevalent in this study. It is worth noting that in Brazil this serovar is considered one of the most frequent among cattle (Hashimoto et al., 2012; F. C.
S. Oliveira et al., 2009), and is more adapted to this species, since it can behave as a reservoir, and once introduced into the herd can establish varying levels (acute or chronic), however, may have low antibody titers in the leptospiraemia phase and yet persist for long periods with intermittent elimination of the bacteria (Hathaway, Little, \& Pritchard, 1986). of infection and may persist for long periods with intermittent elimination of the bacterium (Hathaway et al., 1986). Its transmission occurs mainly by direct exposure to contaminated urine and infected animals may eliminate the agent for several months even after clinical cure (Faine et al., 1999).

In the present study, DNA of Leptospira spp. was detected in a blood sample and identified as L. interrogans through sequencing. This result also corroborates the work of A. F. Oliveira et al. (2018), who also detected DNA in bovine serum samples from two slaughterhouses in northwestern Paraná State.

The importance of the identification of $L$. interrogans in this study is because it can survive up to 200 days under ideal conditions of water and humid soil, so the transmission cycle can be hostto-host dependent, as well as by environmental contamination. This knowledge is essential for the adoption of adequate management measures for the property in question (Bulach et al., 2006).

This is the first report from northwestern Paraná (PR) State related to the molecular identification of L. interrogans from naturally infected milk cows. Based on the results of this work, to enhance production efficiency, new serological and molecular studies are needed on dairy cattle from border regions to characterize the epidemiology of the possible genotypes and their consequences in affected herds.

\section{Acknowledgements}

The authors are grateful to UNIPAR and Fundação Araucária for the funding of this research and to CAPES and CNPq for granting scholarships. 


\section{Ethical Approval}

This project was approved by the Research Ethics Committee Involving Animal Experimentation (CEPEEA) of the University of Paraná (UNIPAR) under protocol 31974/2017.

\section{Declaration of Interest}

The authors report no conflict of interest. The authors alone are responsible for the content and writing of paper.

\section{References}

Ahmed, N., Devi, S. M., De los Á Valverde, M., Vijayachari, P., Machang'u, R. S., Ellis, W. A., \& Hartskeerl, R. A. (2006). Multilocus sequence typing method for identification and genotypic classification of pathogenic Leptospira species. Annals of Clinical Microbiology and Antimicrobials, 23(5), 28. doi: 10.1186/1476-0711-5-28.

Almeida, L. P. D., Martins, L. F. D. S., Brod, C. S., \& Germano, P. M. L. (1994). Levantamento soroepidemiológico de leptospirose em trabalhadores do serviço de saneamento ambiental em localidade urbana da região sul do Brasil. Revista de Saúde Pública, 28(1), 76-81. doi: 10.1590/S003489101994000100009

Bulach, D. M., Zuerner, R. L., Wilson, P., Seemann, T., McGrath, A., Cullen, P. A.,... Adler, B. (2006). Genome reduction in Leptospira borgpetersenii reflects limited transmission potential. Proceedings of the National Academy of Sciences, 103(39), 14560-14565. doi: 10.1073/pnas.0603979103

Faine, S., Adler, B., Bolin, C., \& Perolat, P. (1999). Leptospira and leptospirosis. (2nd ed.). Melbourne: Medical Science.

Freitas, V. P. (2008). A Constituição Federal e a efetividade das normas ambientais. Revista CEJ, 4(10), 114-118. Recuperado de http://www.jf.jus.br/ ojs2/index.php/revcej/article/download/852/1034

Hashimoto, V. Y., Dias, J. A., Chideroli, R. T., Barbara, J. C. A., Brunharo, T. B., Dutra, L. H.,... Freitas, J. C. de. (2015). Epidemiological status of bovine leptospirosis in the State of Paraná, Brazil. Semina: Ciências Agrárias, 36(2), 4341-4355. doi: 10.5433/1679-0359.2015v36n6Supl2p4341
Hashimoto, V. Y., Dias, J. A., Spohr, K. A., Silva, M. C., Andrade, M. G., Müller, E. E., \& Freitas, J. C. (2012). Prevalência e fatores de risco associados à Leptospira spp. em rebanhos bovinos da região centro-sul do estado do Paraná. Pesquisa Veterinária Brasileira, 32(2), 99-105. doi: 10.1590/S0100736X2012000200001

Hathaway, S. C., Little, T. W., \& Pritchard, D. G. (1986). Problems associated with the serological diagnosis of Leptospira interrogans serovar hardjo infection in bovine populations. The Veterinary Record, 119(4), 84-86. doi: 10.1136/vr.119.4.84

Lei $n^{\circ}$ 6.634, de 02 de maio de 1979. Planalto. Brasília: Diário Oficial, 1979. Recuperado de http://www. planalto. gov.br/ccivil_03/LEIS/L6634.htm

McBride, A. J., Athanazio, D. A., Reis, M. G., \& Ko, A. I. (2005). Leptospirosis. Current Opinions in Infectious Diseases 18(5), 376-386. doi: 10.1097/01. qco.0000178824.05715.2c

Oliveira, A. F., Chiderolli, R. T., Gasques, L. S., Gonçalves, A. P. P., Neves, É. D., Ferreira, B. P. M.,... Gonçalves, D. D. (2018). Serological diagnosis and molecular characterization of Leptospira spp. in the blood and urine of bovine females from refrigerated slaughterhouses. Semina: Ciências Agrárias, 39(3), 1125-1134. doi: 10.5433/1679-0359.2018v39n $3 \mathrm{p} 1125$

Oliveira, F. C. S., Azevedo, S. S., Pinheiro, S. R., Viegas, S. A. R. A., Batista, C. S. A., Coelho, C. P.,... Vasconcellos, S. A. (2009). Soroprevalência de leptospirose em fêmeas bovinas em idade reprodutiva no Estado da Bahia. Arquivos do Instituto Biológico, 76(4), 539-546.

Souto, A. M. B., Dalbro, O. F.; Silva, S. R., Coelho, R. M., Yoshida, P. S., Jaudi, L. M. R. (2016). Novas tecnologias na segurança nacional. Revista Faipe, 6(1), 64-70.

Ungerer, L. F. S., \& Reis, S. T. J. (2017). Identificação de bovinos na área de fronteira do Brasil - Região de Mato Grosso do Sul. Revista Uningá, 51(3), 32-38.

Vasconcellos, S. A., Barbarini, O., Jr., Umehara, O., Morais, Z. M. D., Cortez, A., Pinheiro, S. R.,... Ferreira, J. S., Neto. (1997). Leptospirose bovina. Níveis de ocorrência e sorotipos predominantes em rebanhos dos Estados de Minas Gerais, São Paulo, Rio de Janeiro, Paraná, Rio Grande do Sul e Mato Grosso do Sul. Período de janeiro a abril de 1996. Arquivos do Instituto Biológico, 64(2), 7-15. 
